\title{
In Vitro Atileishmanial and Cytotoxic Activities of Annona mucosa (Annonaceae)
}

\author{
de Lima, J. P. S.; Pinheiro, M. L. B.;* Santos, A. M. G.; Pereira, J. L. S.; \\ Santos, D. M. F.; Barison, A.; Silva-Jardim, I.; Costa, E. V.
}

Rev. Virtual Quim., 2012, 4 (6), 692-702. Data de publicação na Web: 11 de novembro de 2012

\author{
http://www.uff.br/rvq
}

\section{Atividade Antileishmania e Citotóxica In Vitro de Annona mucosa (Annonaceae)}

\begin{abstract}
Resumo: A atividade antileishmania dos extratos das folhas e sementes de Annona mucosa, e do alcaloide oxoaporfínico liriodenina isolado do extrato diclorometano das folhas foi avaliada in vitro contra formas promastigotas de três espécies de Leishmania, e formas amastigotas intracelulares de Leishmania amazonensis. A atividade citotóxica foi avaliada contra macrófagos peritoneais de camundongos. O extrato diclorometano das folhas foi o mais ativo contra Leshmania spp. apresentando valores de $\mathrm{Cl}_{50}$ menores que $30 \mu \mathrm{g} \cdot \mathrm{mL}^{-1}$. O alcaloide liriodenina foi o mais citotóxico contra macrófagos peritoneais. Os extratos hexânicos das sementes apresentaram maior indice de seletividade contra Leishmania spp. (IS = 5,93 a 1,54). Todas as amostras foram ativas contra formas amastigotas intracelulares, inibindo, depois de $96 \mathrm{~h}$, mais que $70 \%$ da replicação de amastigotas nos macrófagos infectados. A investigação fitoquímica do extrato diclorometano das folhas de $A$. mucosa levou ao isolamento dos alcaloides oxoaporfínicos atherospermidina (1) e liriodenina (2), identificados com base nos seus dados espectroscópicos, principalmente RMN 1D/2D, e comparação com os dados da literatura.
\end{abstract}

Palavras-chave: Atividade antileishmania; Annona mucosa; alcaloides oxoaporfínicos; Annonaceae.

\begin{abstract}
s
The antileishmanial activity of extracts from the leaves and seeds of Annona mucosa, and of the oxoaporphine alkaloid liriodenine isolated from the dichloromethane extract of the leaves, were evaluated in vitro against promastigote forms of three Leishmania species and against intracellular amastigote forms of L. amazonensis. Cytotoxic activity was evaluated against peritoneal macrophages of mice. The dichloromethane extract from the leaves was the most active against Leishmania spp., showing $\mathrm{IC}_{50}$ values lower than $30 \mu \mathrm{g} \cdot \mathrm{mL}^{-1}$. Liriodenine was the most cytotoxic against peritoneal macrophages. Hexane extracts of seeds showed the highest selectivity index against Leishmania spp. (SI $=5.93$ to 1.54). All samples were active against intracellular amastigote forms, after $96 \mathrm{~h}$ inhibiting more than $70 \%$ of amastigote replication in infected macrophages. Phytochemical investigation of the dichloromethane extract from the leaves of $A$. mucosa led to the isolation of the oxoaporphine alkaloids atherospermidine (1) and liriodenine (2), identified on the basis of their spectroscopic data, mainly 1D/2D NMR, and comparison with literature data.
\end{abstract}

Keywords: Antileishmanial activity; Annona mucosa; oxoaporphine alkaloids; Annonaceae.

\footnotetext{
* Universidade Federal do Amazonas, Departamento de Química, CEP: 69077-000, Manaus-AM, Brazil.

Mlbelem@ufam.edu.br

DOI: $10.5935 / 1984-6835.20120052$
}

Rev. Virtual Quim. |Vol 4| | No. 6| |692-702| 


\section{In Vitro Atileishmanial and Cytotoxic Activities of Annona mucosa (Annonaceae)}

\section{Janaína P. S. de Lima, ${ }^{a}$ Maria L. B. Pinheiro, ${ }^{\text {b,* }}$ Antonio Marcos G.}

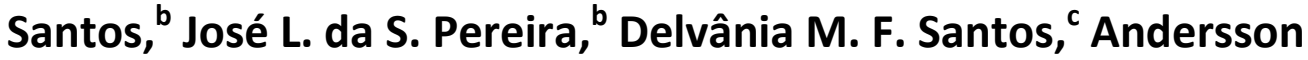
Barison, ${ }^{d}$ Izaltina Silva-Jardim, ${ }^{e}$ Emmanoel V. Costa ${ }^{f}$

\footnotetext{
a Universidade Federal do Amazonas, Instituto de Educação, Agricultura e Ambiente, Campus Vale do Rio Madeira, Rua 29 de agosto, 786, Centro, CEP: 69800-000, Humaitá-AM, Brazil.

${ }^{\text {b}}$ Universidade Federal do Amazonas, Departamento de Química, CEP: 69077-000, Manaus-AM, Brazil.

${ }^{\mathrm{C}}$ Fundação Oswaldo Cruz, Fiocruz Noroeste, Laboratório de Quimioterapia, Instituto de Pesquisas em Patologias Tropicais de Rondônia, Rua da Beira 7671, BR 364, Km 3,5, CEP: 78912-000, Lagoa, Porto Velho-RO, Brazil.

'Universidade Federal do Paraná, Departamento de Química, CEP: 81531-990, Curitiba, PR, Brazil.

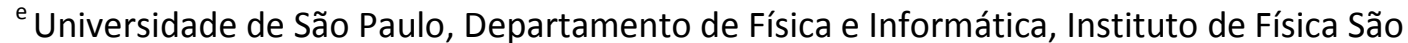
Carlos, Av. Trabalhador São-Carlense, 400, Arnold Schmidt, CEP: 13566-590, São Carlos, SP, Brazil.

${ }^{f}$ Universidade Federal de Sergipe, LABORGANICS, Departamento de Química, 49100-000, São Cristóvão, SE, Brazil.

* Ibelem@ufam.edu.br
}

Recebido em 6 de junho de 2012. Aceito para publicação em 6 de setembro de 2012

1. Introduction

2. Experimental

2.1. General

2.2. Animal Experimentation Guidelines

2.3. Plant Material

2.4. Extraction and Isolation Procedures

2.5. In vitro Antileishmanial Assay

2.6. Statistical Analysis

3. Results and Discussion

4. Conclusions 


\section{Introduction}

Leishmaniasis is a group of tropical diseases caused by several species of protozoa parasites belonging to the genus Leishmania. Leishmaniasis affects more than 12 million people in 88 countries worldwide, constituting a growing public health problem in Africa, Asia and Latin America. ${ }^{1}$ The existence of several different species of Leishmania makes it difficult to reduce the infection rate of the diseases caused by this parasite, in both tegumentary and visceral forms. The different epidemiological status of endemic regions and the trend toward urbanization require the adoption of different strategies for the control of leishmaniasis in Brazil. ${ }^{2}$

In the Brazilian Amazon, L. (Leishmania) amazonensis, L. (Viannia) braziliensis and $L$. (Viannia) guyanensis are the major causal agents of American Tegumentary Leishmaniasis (ATL). Three forms of the disease are described: cutaneous leishmaniasis, mucocutaneous leishmaniasis, and diffuse cutaneous leishmaniasis. Cutaneous leishmaniasis is usually caused by $L$. amazonensis, $L$. braziliensis or $L$. guyanensis. Mucocutaneous leishmaniasis is usually caused by $L$. braziliensis or $L$. guyanensis, following cure of the initial cutaneous leishmaniasis. Diffuse cutaneous leishmaniasis is caused by L. amazonensis. ${ }^{3}$ Cutaneous forms may heal spontaneously within a few months, or may develop into the other tegumentary leishmaniasis, which can cause serious facial disfiguration, morbidity, or mortality. ${ }^{4}$

The current status of ATL, evaluated in Brazilian municipalities based on the records of the Health and Sanitation Department of the Ministry of Health, ${ }^{3}$ revealed incidences ranging from 10.45 to 22.9 per 100,000 inhabitants, clearly indicating a geographical expansion of the disease. The Northern region has $34.9 \%$ of the total cases in the country and a global risk of acquiring the disease of 92.3 per 100,000 inhabitants, five times the national average.
Nowadays, chemotherapy for leishmaniasis is still based mainly on daily intramuscular injections of pentavalent antimonials (Glucantime ${ }^{\circledR}$ and Pentostam ${ }^{\circledR}$ ), diamines (Pentamidine ${ }^{\circledR}$ ) and an antifungal polyene (Amfotericine ${ }^{\circledR}$ B), which are toxic, expensive, generate resistance, and require long-term treatment. There is an urgent need to develop new, more-effective and safer therapeutic agents in the fight against leishmaniasis. ${ }^{4}$

Advances in combating leishmaniasis using natural products have been recently reviewed. $^{5,6}$ Studies of plants producing alkaloids and acetogenins have yielded promising results against Leishmania spp., in particular extracts from species of the family Annonaceae. ${ }^{6}$

Annonaceae is a group of aromatic trees, shrubs, and lianas that occur mainly in tropical and subtropical regions. Previous chemical and pharmacological investigations on some species of this family have indicated the presence of important bioactive compounds with various pharmacological activities, including antiparasitic, in particular antileishmanial. ${ }^{7-14}$

Continuing our chemical and biological antileishmanial studies of members of the Annonaceae, we investigated the species Annona mucosa Jacq. [synonym Rollinia mucosa (Jacq.) Baill]. ${ }^{15}$ This species provides the delicious fruit biribá, and popular reports reveal the use of its leaf extracts for the elimination of fleas and other insects infesting domestic animals. Chemical and pharmacological studies of species of Annonaceae have revealed the presence of alkaloids, acetogenins and lignoids, with proven antiprotozoal, antimicrobial and antifungal effects, ${ }^{16-18}$ suggesting great chemical and pharmacological potential. In this study, extracts from $A$. mucosa (leaves and seeds), and the oxoaporphine alkaloid liriodenine, isolated from a dichloromethane extract of the leaves, were investigated in vitro against promastigote forms of $L$. amazonensis, $L$. braziliensis and $L$. guyanensis, and intracellular amastigote forms of $L$. amazonensis. The cytotoxicity to 
mice peritoneal macrophages was also evaluated.

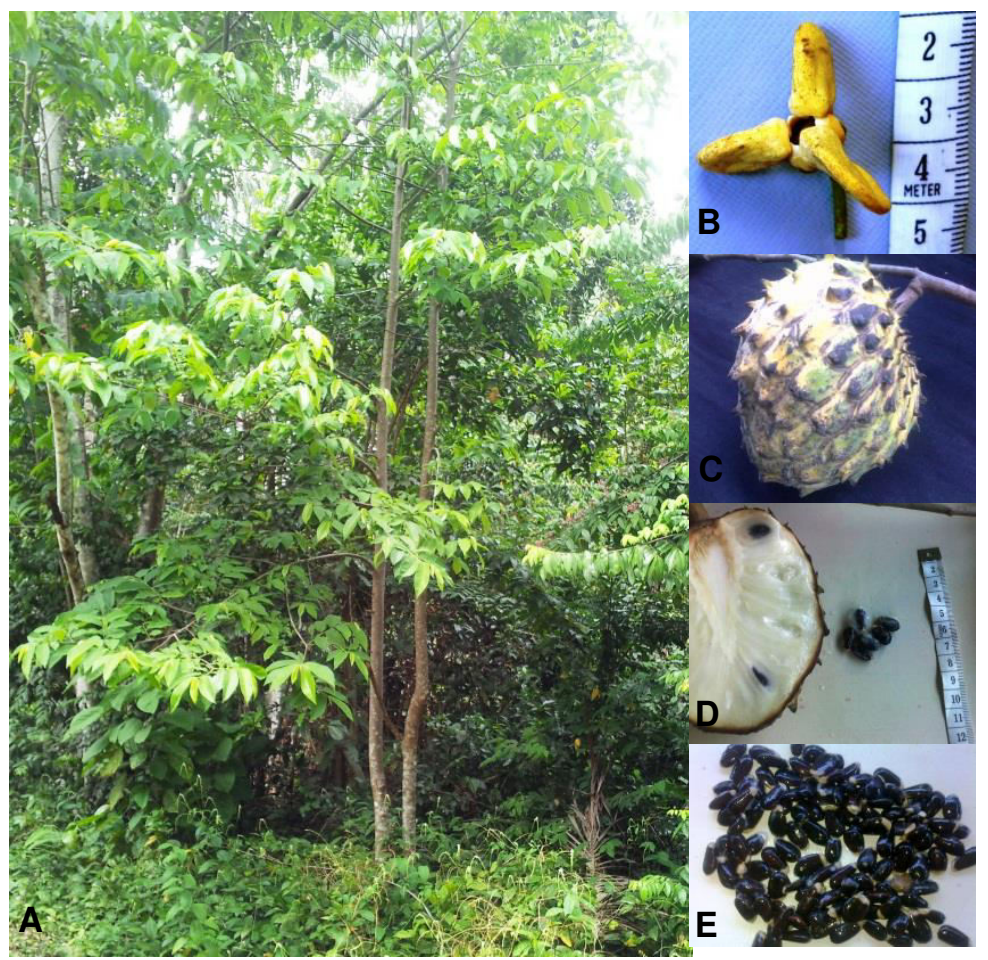

Figure 1. Photos of Annona mucosa Jacq. A, All Plant; B, Flower detail; C, Fruit; D, Fruit in longitudinal section; E, Seeds. (Author: J. L. S. Pereira)

\section{Experimental}

\subsection{General}

Melting points (m.p.) were measured using a Microquímica MQAPF 301 Model. 1D and 2D NMR experiments were acquired in $\mathrm{CDCl}_{3}$ at $293 \mathrm{~K}$ on a Bruker AVANCE $400 \mathrm{NMR}$, operating at 400 and $100 \mathrm{MHz}$ for ${ }^{1} \mathrm{H}$ and ${ }^{13} \mathrm{C}$, respectively. The spectrometer was equipped with a 5-mm multinuclear direct detection probe with $z$-gradient. One-bond and longrange ${ }^{1} \mathrm{H}^{13} \mathrm{C}$ correlation (HSQC and $\mathrm{HMBC}$ ) experiments were optimized for an average coupling constant ${ }^{1} J_{(\mathrm{C}, \mathrm{H})}$ and ${ }^{\mathrm{LR}} J_{(\mathrm{C}, \mathrm{H})}$ of 140 and $8 \mathrm{~Hz}$, respectively. All ${ }^{1} \mathrm{H}$ - and ${ }^{13} \mathrm{C}-\mathrm{NMR}$ chemical shifts $(\boldsymbol{\delta})$ are given in $\mathrm{ppm}$, with respect to the TMS signal at $0.00 \mathrm{ppm}$ as internal reference and the coupling constants $(J)$ in $\mathrm{Hz}$. Silica gel 60 (70-230 mesh) was used for column chromatography, and silica gel 60 $\mathrm{F}_{254}$ was used for analytical $(0.25 \mathrm{~mm})$, and preparative $(1.00 \mathrm{~mm})$ TLC (thin layer chromatography). Compounds were visualized by exposure under $U_{254 / 366}$ light, spraying $p$-anisaldehyde reagent followed by heating on a hot plate, as well as spraying with Dragendorff's reagent.

\subsection{Animal experimentation guidelines}

The experimental protocols conformed to the ethical principles in animal research adopted by the Comissão de Ética no Uso de Animais of the Instituto de Pesquisas em Patologias Tropicais (CEUA/IPEPATRO 2011/01). Male BALB/c mice were housed in 
temperature-controlled rooms and provided water and food ad libitum until used.

\subsection{Plant Material}

Leaves and fruits of $A$. mucosa were collected from the campus of the Universidade Federal do Amazonas (UFAM) [coordinates: S $03^{\circ} 06^{\prime} 2.4^{\prime \prime}$ W $59^{\circ} 58^{\prime} 27.7^{\prime \prime}$ ], Manaus, Amazonas, Brazil, in September 2007. The specimen was identified by a plant specialist of the UFAM Department of Biology, and a voucher specimen has been deposited in the Herbarium of this University, with register number HUAM/UFAM 8148.

\subsection{Extraction and Isolation Procedures}

Dried and powdered leaves (900 g) of $A$. mucosa were successively extracted with $n$ hexane, dichloromethane and methanol, to yield hexane $(18.4 \mathrm{~g})$, dichloromethane (42.4 $\mathrm{g})$, and methanol (19.6 g) extracts, after removal of each solvent. A similar procedure was followed with the seeds from fruits (300 $\mathrm{g})$, using only hexane and methanol as solvents to obtain hexane $(5.0 \mathrm{~g})$, and methanol (15.0 g) extracts, respectively. TLC investigations indicated that the dichloromethane extract of the leaves contained the highest concentration of alkaloids. A part of this extract (11.2 g) was initially subjected to an acid-base extraction ${ }^{12}$ to give dichloromethane alkaloid $(0.25 \mathrm{~g})$ and dichloromethane neutral $(6.0 \mathrm{~g})$ fractions. The alkaloid fraction was subjected to silica gel column chromatography eluted with the gradient systems: hexane-dichloromethane from 100:0 to 10:90, followed by dichloromethane-methanol from 100:0 to $50: 50$, yielding 56 subfractions. The eluted subfractions were evaluated and pooled according to TLC analysis, to afford 6 groups of fractions (GF1-GF6). GF3 (20.0 mg) was purified by preparative TLC eluted with hexane-acetone (60:40, three times) affording 1 (2.0 $\mathrm{mg})$ and 2 (10.0 $\mathrm{mg})$ respectively.
Atherospermidine (1): Orange crystals $\left(\mathrm{CH}_{2} \mathrm{Cl}_{2}: \mathrm{MeOH} 3: 1\right)$; mp $285-288{ }^{\circ} \mathrm{C}$ (lit. 286$\left.287{ }^{\circ} \mathrm{C}\right)$; identified by comparison with literature data (co-TLC, mp, ${ }^{1} \mathrm{H}-\mathrm{NMR}$ and ${ }^{13} \mathrm{C}$ NMR). ${ }^{19}$

Liriodenine (2): Yellow crystals $\left(\mathrm{CH}_{2} \mathrm{Cl}_{2}: \mathrm{MeOH} 3: 1\right) ; \mathrm{mp} 279-280{ }^{\circ} \mathrm{C}$ (lit. 281$\left.282{ }^{\circ} \mathrm{C}\right)$; identified by comparison with literature data (co-TLC, mp, ${ }^{1} \mathrm{H}-\mathrm{NMR}$ and ${ }^{13} \mathrm{C}$ NMR). ${ }^{19}$

\subsection{In vitro Antileishmanial Assay}

\subsubsection{Parasites}

The antileishmanial activity was evaluated against promastigote forms of Leishmania (Leishmania) amazonensis (IFLA/BR/67/PH8) and Leishmania (Viannia) guyanensis (MHOM/BR/75/M4147) cultured in RPMI 1640 medium supplemented with $10 \%(\mathrm{v} / \mathrm{v})$ heat-inactivated fetal bovine serum (FBS) and $50 \mu \mathrm{g} \cdot \mathrm{mL}^{-1}$ gentamycin at $24{ }^{\circ} \mathrm{C}$ in a tissue culture flask, and the promastigote forms of Leishmania (Viannia) braziliensis (MHOM/BR/75/M2903) cultured in Schneider's Drosophila medium supplemented with $10 \%(\mathrm{v} / \mathrm{v})$ heatinactivated $\mathrm{FBS}, 5 \%(\mathrm{v} / \mathrm{v})$ male human urine and $50 \mu \mathrm{g} \cdot \mathrm{mL}^{-1}$ gentamycin at $24^{\circ} \mathrm{C}$ in a tissue culture flask.

\subsubsection{Antileishmanial activity against promastigote forms}

A modification of the method described by Camacho et al. ${ }^{20}$ was used to assess the in vitro antileishmanial activity. The screening was performed in eppendorfs maintained at $24^{\circ} \mathrm{C}$. Promastigote forms of Leishmania spp. $\left(5.0 \times 10^{5}\right.$ parasites. $\left.\mathrm{mL}^{-1}\right)$ were exposed to six concentrations $\left(6,12,25,50\right.$ and $100 \mu \mathrm{g} \cdot \mathrm{mL}^{-}$ $\left.{ }^{1}\right)$ of each extract and liriodenine. The samples were dissolved in DMSO. Up to $0.7 \%$ $(v / v)$, DMSO had no effect on parasite growth. The activity of the samples was 
evaluated for six days by counting microscopically the number of live parasites that showed flagellar motility, using a Neubauer hemocytometer. The counts were compared with those of controls grown without a sample of extract, and with pentamidine isethionate (Sigma/P0547) used as the reference antileishmanial drug. Each concentration was assayed in duplicate. Results are expressed as concentrations inhibiting parasite growth by $50 \%\left(\mathrm{IC}_{50}\right)$ after six days of incubation.

\subsubsection{Antileishmanial activity against intracellular amastigote forms}

The in vitro sensitivity of amastigote forms of Leishmania amazonensis (IFLA/BR/67/PH8) was determined in a mice peritoneal macrophage model. Peritoneal macrophages were collected from the peritoneal cavity of male BALB/c mice by washing with RPMI 160 medium four days after an intraperitoneal injection of $2.0 \mathrm{~mL}$ of sodium thioglycolate. The macrophages were dispensed into flatbottomed plastic 24-well tissue plates containing glass coverslips $(13 \mathrm{~mm})$, at a concentration of $5 \times 10^{5} /$ well $\left(500 \mu \mathrm{L}\right.$.well ${ }^{-1}$ ) in RPMI 1640 medium supplemented with $10 \%(\mathrm{v} / \mathrm{v})$ heat-inactivated fetal bovine serum (FBS) and $50 \mu \mathrm{g} \cdot \mathrm{mL}^{-1}$ gentamycin, and incubated at $37{ }^{\circ} \mathrm{C}$ in a $5 \% \mathrm{CO}_{2}$ /air mixture. After $24 \mathrm{~h}$, non-adherent cells were removed by washing with pre-warmed phosphatebuffered saline (PBS), and then the plated macrophages were infected with Leishmania amazonensis promastigotes, at a ratio of $10: 1$, and incubated at $34{ }^{\circ} \mathrm{C}$ in a $5 \% \mathrm{CO}_{2} /$ air mixture. The culture medium was renewed after $24 \mathrm{~h}$, and a new culture medium containing $25 \mu \mathrm{g} \cdot \mathrm{mL}^{-1}$ of each sample was added and the plates were incubated in the same conditions described above. Each extract and liriodenine were assayed in triplicate. The experiments were stopped at day 2, 3 or 5. The method described by Fumorola et al. ${ }^{21}$ was used to make direct counts of the intracellular amastigotes. The infected macrophages from each sample were stained with May-Grunwald/Giemsa, and then evaluated microscopically to determine the percentage of infected macrophages and the number of amastigote forms per macrophage; 200 macrophages were inspected in each sample. ${ }^{22}$

\subsubsection{Cytotoxicity in peritoneal macrophages}

Cytotoxicity was studied after $96 \mathrm{~h}$ incubation of peritoneal macrophages with concentrations ranging from 6 to $100 \mu \mathrm{g} \cdot \mathrm{mL}^{-1}$ of each extract and liriodenine. Peritoneal macrophages were collected from the peritoneal cavity of male BALB/c mice, as described in section 2.5.3. The macrophages were plated into 24-well tissue plates and incubated at $37{ }^{\circ} \mathrm{C}$ in a $5 \% \mathrm{CO}_{2}$ /air mixture. The viability of the macrophages was determined by direct counts, using a Neubauer hemocytometer. The counts were compared with those of controls incubated without a sample and with the antileishmanial reference drug pentamidine isethionate. Each concentration was assayed in triplicate. Results are expressed as 50\% lethal concentrations $\left(\mathrm{LC}_{50}\right)$ after $96 \mathrm{~h}$ of incubation.

\subsection{Statistical Analysis}

All results were expressed as mean \pm SEM for $n$ experiments. Statistical evaluation was undertaken by analysis of variance (ANOVA) followed by the Student-Newman-Keuls test for multiple comparisons. A $P$ value of less than 0.05 was considered statistically significant.

The $\mathrm{IC}_{50}$ and $\mathrm{LC}_{50}$ values at the $95 \%$ confidence interval were calculated using sigmoid dose-response curves in Graph Pad Prism 5.01 software. 


\section{Results and Discussion}

Phytochemical investigation of the dichloromethane extract from the leaves of A. mucosa led to the isolation of the oxoaporphine alkaloids atherospermidine (1) and liriodenine (2) (Figure 2). The structures of these alkaloids were elucidated based on their spectroscopic data, mainly $1 \mathrm{D}$ and $2 \mathrm{D}$ $\mathrm{NMR}$, and also comparison with literature data. ${ }^{19}$ Atherospermidine (1) is reported for the first time in this species, and compound 2 has been previously described in the stem and fruits of this plant. ${ }^{16}$ Atherospermidine (1) and liriodenine (2) are two oxoaporphine alkaloids that are widely found in almost all genera of Annonaceae, for which $\mathbf{2}$ is considered a chemotaxonomic marker. ${ }^{23}$

The extracts and liriodenine isolated from A. mucosa were screened for antileishmanial activity against $L$. amazonensis, $L$. braziliensis and $L$. guyanensis promastigote forms. Because of the small yield of atherospermidine, this compound was not screened. The results of the evaluation of antileishmanial activity ( $\left(\mathrm{C}_{50}\right.$ values) of the seven samples are shown in Table 1 . The $I C_{50}$ values are the means of six determinations. The samples were classified as highly active $\left(\mathrm{IC}_{50}<10 \mu \mathrm{g} \cdot \mathrm{mL}^{-1}\right)$, active $\left(10<\mathrm{IC}_{50}<50\right.$ $\left.\mu \mathrm{g} \cdot \mathrm{mL}^{-1}\right)$, moderately active $\left(50<\mathrm{IC}_{50}<100\right.$ $\left.\mu \mathrm{g} \cdot \mathrm{mL}^{-1}\right)$ and non-active $\left(\mathrm{IC}_{50}>100 \mu \mathrm{g} \cdot \mathrm{mL}^{-1}\right){ }^{20}$<smiles>COc1c2c(c3c4c(ccnc14)C(=O)c1ccccc1-3)OCO2</smiles>

(1)<smiles>O=C1c2ccccc2-c2c3c(cc4ccnc1c24)OCO3</smiles>

(2)
Figure 2. Alkaloids isolated from leaves of Annona mucosa

Table 1. In vitro antileishmanial activity forms of extracts and liriodenine from Annona mucosa on promastigotes of Leishmania spp.

\begin{tabular}{|c|c|c|c|}
\hline \multirow[t]{2}{*}{ Extract/fraction } & \multirow[t]{2}{*}{$\mathbf{P}^{\mathbf{a}}$} & \multicolumn{2}{|c|}{$\begin{array}{c}\text { Leishmania sp. }^{\mathrm{b}} \\
\mathrm{IC}_{50}\left(\mu \mathrm{g} \cdot \mathrm{mL}^{-1}\right) \pm \mathrm{SEM}^{\mathrm{C}}\end{array}$} \\
\hline & & $\mathrm{PH} 8$ & M2903 \\
\hline Hexane extract & $\mathrm{L}$ & $24.24 \pm 1.51$ & $65.27 \pm 1.20$ \\
\hline Dichloromethane extract & $\mathrm{L}$ & $9.32 \pm 0.56$ & $27.42 \pm 5.42$ \\
\hline Methanol extract & $\mathrm{L}$ & $28.32 \pm 1.15$ & $44.74 \pm 5.89$ \\
\hline Hexane extract & $S$ & $44.22 \pm 5.64$ & $170.15 \pm 1.46$ \\
\hline Methanol extract & $\mathrm{S}$ & $46.54 \pm 4.95$ & $133.17 \pm 5.41$ \\
\hline Compound & & \multicolumn{2}{|c|}{$\mathrm{IC}_{50}\left(\mu \mathrm{g} \cdot \mathrm{mL}^{-1}\right) \pm \mathrm{SEM}^{\mathrm{c}}$} \\
\hline Liriodenine & & $1.43 \pm 0.58$ & $55.92 \pm 3.55$ \\
\hline Pentamidine $^{d}$ & & $0.07 \pm 0.00$ & $5.48 \pm 0.00$ \\
\hline
\end{tabular}

The in vitro cytotoxic activities ( $\mathrm{LC}_{50}$ values) of the extracts and liriodenine against peritoneal macrophages are shown in Table 2. The $L C_{50}$ values are the means of three determinations. The samples were classified as highly toxic $\left(\mathrm{LC}_{50}<10 \mu \mathrm{g} \cdot \mathrm{mL}^{-1}\right)$, toxic $(10<$ $\left.\mathrm{LC}_{50}<100 \mu \mathrm{g} \cdot \mathrm{mL}^{-1}\right)$, moderately toxic $(100<$ $\mathrm{LC}_{50}<1000 \mu \mathrm{g} \cdot \mathrm{mL}^{-1}$ ) and potentially non-toxic 
$\left(\mathrm{LC}_{50}>1000 \mu \mathrm{g} \cdot \mathrm{mL}^{-1}\right) .{ }^{20}$ The results showed that four samples were toxic to mice peritoneal macrophages, and two extracts were moderately toxic. Cytotoxic activity $\left(\mathrm{LC}_{50}\right)$ was related to antileishmanial activity by determining their corresponding selectivity index $\left(\mathrm{SI}=\mathrm{LC}_{50} / \mathrm{IC}_{50}\right)$ as shown in
Table 2. A value lower than 1 indicates that they are more toxic to peritoneal macrophages than to the parasites, and a value greater than 1 indicates higher selectivity against the parasites than against the peritoneal macrophages.

Table 2. Cytotoxicity and selectivity index of extracts and liriodenine from Annona mucosa

\begin{tabular}{|c|c|c|c|c|}
\hline \multirow[t]{2}{*}{ Extract/fraction } & \multirow[t]{2}{*}{$\mathbf{P}^{\mathrm{a}}$} & \multirow{2}{*}{$\begin{array}{c}\text { Cytotoxicity }^{\mathrm{b}} \\
\mathrm{LC}_{50}\left(\mu \mathrm{g} \cdot \mathrm{mL}^{-1}\right) \pm \mathrm{SEM}^{\mathrm{c}}\end{array}$} & \multicolumn{2}{|c|}{$S I^{d}$} \\
\hline & & & PH8 & M2903 \\
\hline Hexane extract & $L$ & $62.63 \pm 4.10$ & 2.58 & 0.95 \\
\hline Dichloromethane extract & L & $24.07 \pm 0.72$ & 2.58 & 0.87 \\
\hline Methanol extract & L & $29.41 \pm 0.89$ & 1.03 & 0.65 \\
\hline Hexane extract & $S$ & $262.33 \pm 5.81$ & 5.93 & 1.54 \\
\hline Methanol extract & $\mathrm{S}$ & $139.00 \pm 3.13$ & 2.98 & 1.04 \\
\hline \multirow[t]{2}{*}{ Compound } & & Cytotoxicity $^{\mathrm{b}}$ & \multicolumn{2}{|c|}{$\mathrm{SI}^{\mathrm{d}}$} \\
\hline & & $\mathrm{LC}_{50}\left(\mu \mathrm{g} \cdot \mathrm{mL}^{-1}\right) \pm \mathrm{SEM}^{\mathrm{c}}$ & PH8 & M2903 \\
\hline Liriodenine & & $19.11 \pm 1.06$ & 13.36 & 0.34 \\
\hline Pentamidine $^{\mathrm{e}}$ & & $51.99 \pm 0.58$ & 742.71 & 9.48 \\
\hline
\end{tabular}

The samples were also assayed on intracellular amastigote forms in three independent experiments. The percentage of infected macrophages (Figure $3 \mathrm{~A}$ ) and the parasite load (Figure 3B) decreased over time. The percentage of infected macrophages at 24, 48 and 96 hours showed that the activity reduction was maintained for the hexane and dichloromethane extracts from the leaves of $A$. mucosa and liriodenine. The observed lower activity of the alkaloid liriodenine than of the plant extracts over this period can be explained only after complete investigation of the chemical constituents and biological evaluation of these extracts. The macrophages showed no apparent effect of toxicity such as rounding or detachment, even in the presence of the samples at $25 \mu \mathrm{g} \cdot \mathrm{mL}^{-1}$.

Few studies have examined the effects of plant extracts on L. guyanensis, but some studies have shown antileishmanial activity of extracts of the genus Rollinia (presently merged in Annona) against promastigote forms of $L$. amazonensis, $L$. braziliensis and $L$. donovani. ${ }^{25,26}$ In our study, the dichloromethane extract of the leaves proved to be more active than the other extracts assayed, inhibiting the growth of promastigotes with $\mathrm{IC}_{50}$ values between 9.32 to $27.42 \mu \mathrm{g} \cdot \mathrm{mL}^{-1}$. It was classified as toxic with $\mathrm{LC}_{50}$ of $24.07 \mu \mathrm{g} \cdot \mathrm{mL}^{-1}$, and caused total lysis of macrophages at $100 \mu \mathrm{g} \cdot \mathrm{mL}^{-1}$. The results indicated that the hexane and methanol extracts of leaves were effective in inhibiting the growth of promastigote forms of $L$. amazonensis, with $\mathrm{IC}_{50}$ values from 24.24 to $28.32 \mu \mathrm{g} \cdot \mathrm{mL}^{-1}$, as well as promastigotes of $L$. braziliensis, with $\mathrm{IC}_{50}$ values from 44.74 to $65.27 \mu \mathrm{g} \cdot \mathrm{mL}^{-1}$ and were classified as toxic with $\mathrm{LC}_{50}$ of 62.63 and $29.41 \mu \mathrm{g} \cdot \mathrm{mL}^{-1}$, respectively. The hexane and methanol extracts of the seeds were effective in inhibiting the growth of promastigotes of L. amazonensis, with $\mathrm{IC}_{50}$ values from 44.22 to $46.54 \mu \mathrm{g} \cdot \mathrm{mL}^{-1}$ and were classified as toxic with $\mathrm{LC}_{50}$ of 262.33 and $139 \mu \mathrm{g} \cdot \mathrm{mL}^{-1}$, 
respectively. In the same test, the reference drug pentamidine had an $\mathrm{IC}_{50}$ value from 0.07 to $5.48 \mu \mathrm{g} \cdot \mathrm{mL}^{-1}$ and was classified as toxic, with $\mathrm{LC}_{50}$ of $51.99 \mu \mathrm{g} \cdot \mathrm{mL}^{-1}$.

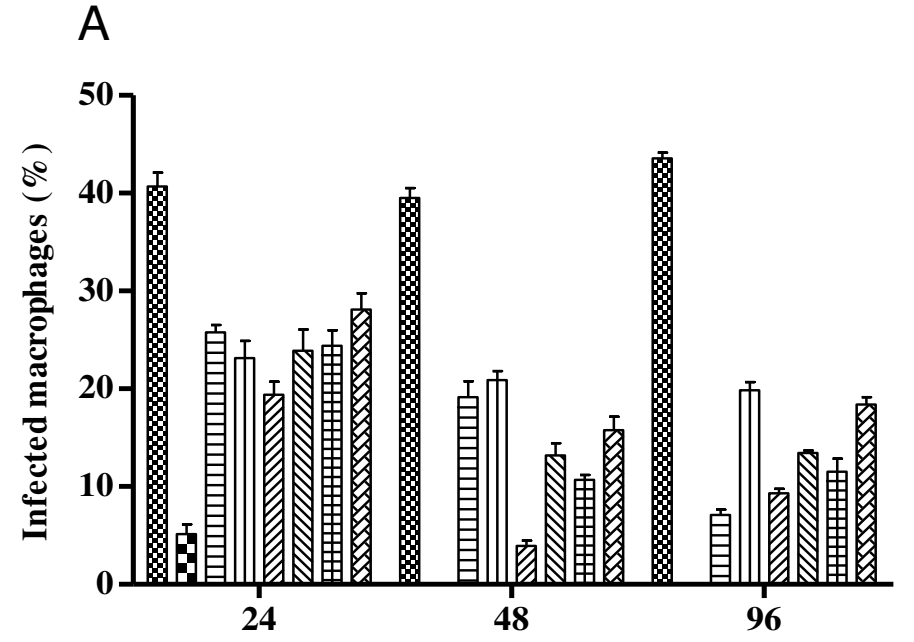

Time (h)
$\$$ Control

Eentamidine

Elkaloid liriodenine

एा) Dichloromethane extract leaves

שII Hexane extract leaves

Methanol extract leaves

Hexane extract seeds

Methanol extract seeds

B

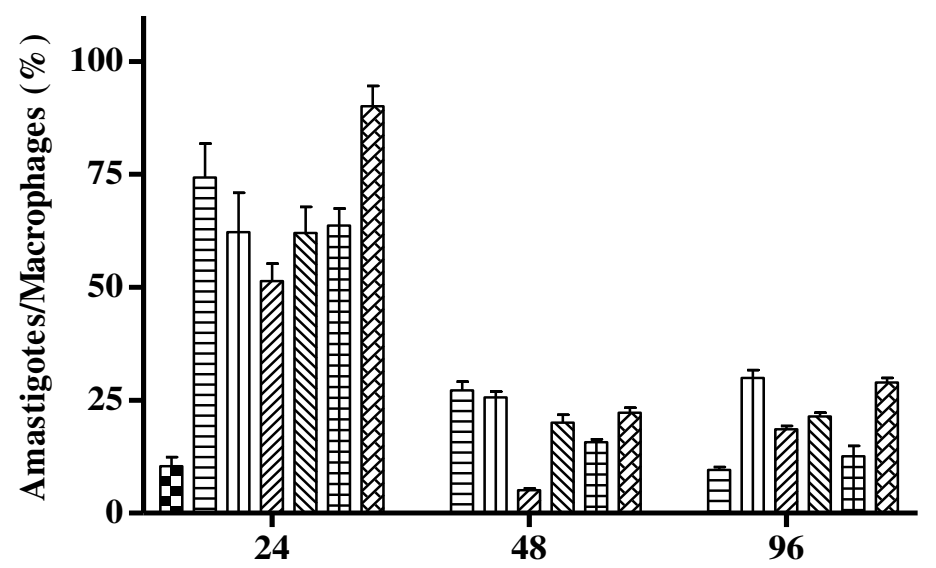

묘 Pentamidine

E Alkaloid liriodenine

एा Dichloromethane extract leaves

שIA Hexane extract leaves

Methanol extract leaves

Hexane extract seeds

Methanol extract seeds

Time (h)

(A) Percentage of macrophages infected. (B) Parasite load (number of amastigotes/macrophage) as a percentage of that in controls, taken as $100 \%$. Controls averaged 4.86 amastigotes/macrophage incubated for $24 \mathrm{~h}, 8.28$ amastigotes/macrophage incubated for $48 \mathrm{~h}$, and 7.38 amastigotes/macrophage incubated for $96 \mathrm{~h}$. The data are the mean values $\pm \mathrm{SEM}$ of six mice.

Figure 3. Antileishmanial activity of extracts and liriodenine from Annona mucosa on intracellular amastigotes

Some previous reports describe the antileishmanial activity of the alkaloid liriodenine. ${ }^{12,} 26,27$ Antileishmanial activity has been reported to differ against promastigotes of L. amazonensis $\left(\mathrm{IC}_{50} 5-100 \mu \mathrm{g} \cdot \mathrm{mL}^{-1}\right), \mathrm{L}$. braziliensis $\left(\mathrm{IC}_{50} 5-100 \mu \mathrm{g} \cdot \mathrm{mL}^{-1}\right)$ and $L$. donovani $\left(\mathrm{IC}_{50} 3.12\right.$ - $\left.100 \mu \mathrm{g} \cdot \mathrm{mL}^{-1}\right)$. In our study, this compound inhibited the growth of promastigotes, showing activity against $L$. amazonensis with $\mathrm{IC}_{50}$ of $1.43 \mu \mathrm{g} \cdot \mathrm{mL}^{-1}, \mathrm{~L}$. 
braziliensis with $\mathrm{IC}_{50}$ of $55.92 \mu \mathrm{g} \cdot \mathrm{mL}^{-1}$ and $L$. guyanensis with $\mathrm{IC}_{50}$ of $0.84 \mu \mathrm{g} \cdot \mathrm{mL}^{-1}$. It has been suggested ${ }^{5}$ that the observed differences in the biological activity of this metabolite against the same species of Leishmania could be due to the use of biphasic or liquid media to evaluate antileishmanial activity. When tested for cytotoxicity, liriodenine was classified as toxic with $\mathrm{LC}_{50}$ of $19.11 \mu \mathrm{g} \cdot \mathrm{mL}^{-1}$, causing total lysis of the macrophages at $100 \mu \mathrm{g} \cdot \mathrm{mL}^{-1}$ and was the most selective against $L$. guyanensis with SI of 22.75. Nevertheless, against $L$. braziliensis, liriodenine is non-selective, with SI of 0.34. This result suggests that cytotoxicity does not always correlate with antileishmanial activity. Leishmania spp. differ intrinsically in their drug sensitivity, as seen in Table 1 . Croft and Coombs ${ }^{28}$ suggested a possible explanation for this variation, that different Leishmania spp. not only reside in different macrophage types, but also have differing adaptations that facilitate intracellular survival.

The samples were active against intracellular amastigote forms of $L$. amazonensis at concentrations of $25 \mu \mathrm{g} \cdot \mathrm{mL}^{-1}$. In our study, pentamidine was highly active, and after $48 \mathrm{~h}$ of incubation, eliminated $100 \%$ of infected macrophages. Nevertheless, the toxicity of pentamidine makes it a second choice, for use when treatment with antimony compounds is not effective. ${ }^{5}$ In the same conditions, the extracts of $A$. mucosa and liriodenine showed more than $80 \%$ eliminated infected macrophages and 70\% eliminated intracellular amastigotes. Because the extracts are a complex mixture of substances, purification of the active compounds might considerably increase their antileishmanial activity.

Additionally, in our assays, almost all the extracts showed antileishmanial activity, mainly the dichloromethane extract, which provided the cytotoxic and antileishmanial oxoaporphine alkaloids atherospermidine and liriodenine. ${ }^{19}$ Therefore, these alkaloids may be responsible for the antileishmanial activity observed.

\section{Conclusions}

This study resulted in the isolation and identification of two oxoaporphine alkaloids, atherospermidine (1) and liriodenine (2), from the leaves of $A$. mucosa, 1 is reported for the first time in this species. These results contribute to the chemotaxonomic understanding of the family Annonaceae, especially the genus Annona. The results obtained in this study also confirm the importance of the selection of plant extracts used in folk medicine in screening programs in the search for new antileishmanial agents. Further investigation including the oxoaporphine alkaloid liriodenine and other constituents extracted from $A$. mucosa should focus on understanding their mechanisms of action, and encourage us to continue in vitro and in vivo investigations.

\section{Acknowledgments}

The authors are grateful to FAPEAM, CNPq and FINEP for financial support and scholarships.

\section{References}

${ }^{1}$ Site of World Health Organization. The leishmaniasis and Leishmania/HIV coinfections. 2002. Available in: <http://www.who.int/leishmaniasis/burden/ hiv_coinfection/en/ATMP1.pdf>. Access: 1 december 2011.

${ }^{2}$ Costa, J. M. L. Gaz. Méd. Bahia 2005, 75, 3. [Link]

${ }^{3}$ Site of the Ministério da Saúde. Available in: <http://portal.saude.gov.br/portal/arquivos/ pdf/manual_Ita_2ed.pdf $>$ Access: 1 december 2011.

${ }^{4}$ Teles, C. B. G.; Moreira, L. S.; Silva, A. A. E.; Facundo, V. A.; Zuliani, J. P.; Stabéli, R. G.; 
Silva-Jardim, I. J. Braz. Chem. Soc. 2011, 22, 936. [CrossRef]

${ }^{5}$ Chan-Bacab, M. J.; Peña-Rodriguez, L. M. Nat. Prod. Rep. 2001, 18, 674. [CrossRef] [PubMed]

${ }^{6}$ Rocha, L. G.; Almeida, J. R. G. S.; Macêdo, R. O.; Barbosa-Filho, J. M. Phytomedicine 2005, 12, 514. [CrossRef] [PubMed]

${ }^{7}$ Rupprecht, J. K.; Hui, Y. H.; MacLaughlin, J. L. J. Nat. Prod. 1990, 53, 237. [CrossRef] [PubMed]

${ }^{8}$ Queiroz, E. F.; Roblot, F.; Cavé, A.; Paulo, M. Q.; Fournet, A. J. Nat. Prod. 1996, 59, 438. [CrossRef] [PubMed]

${ }^{9}$ Cavé, A.; Cortes, D.; Figadère, A.; Laurens, A.; Pettit, G. R. In Progress in the Chemistry of Organic Natural Products; Herz, W.; Kirby, G.; Moore, R.; Steglich, W.; Tamm, C., eds.; Springer-Verlag: Wien and New York 1997, $330 \mathrm{p}$.

${ }^{10}$ Boyom, F. F.; Ngouana, V.; Zollo, P. H. A.; Menut, C.; Bessiere, J. M.; Gut, J.; Rosenthal, P. J. Flavour Frag. J. 1996, 11, 333. [CrossRef]

${ }^{11}$ Montenegro, H.; Gutiérrez, M.; Romero, L. I.; Ortega-Barria, E.; Capson, T. L.; Rios, L. C. Planta Med. 2003, 69, 677. [CrossRef] [PubMed]

${ }^{12}$ Costa, E. V.; Pinheiro, M. L. B.; Xavier, C. M.; Silva, J. R. A.; Amaral, A. C. F.; Souza, A. D. L.; Barison, A.; Campos, F. R.; Ferreira, A. G.; Machado, G. M. C.; Leon, L. L. P. J. Nat. Prod. 2006, 69, 292. [CrossRef] [PubMed]

${ }^{13}$ Osorio, E. J. D.; Montoya, G. L. P.; Arango, G. J. A. Vitae (Medellín) 2006, 13, 61.

${ }^{14}$ Costa, E. V.; Pinheiro, M. L. B.; Silva, J. R. A.; Maia, B. H. L. N. S.; Duarte, M. C. T.; Amaral, A. C. F.; Machado, G. M. C.; Leon, L. L. Quím. Nova 2009, 32, 78. [CrossRef]

${ }^{15}$ Rainer, H. Naturlist Mus. Wien 2007, 108B, 191. [Link]

${ }^{16}$ Chen, Y. Y.; Chang, Fr.; Wu, Yc. J. Nat. Prod. 1996, 59, 904. [CrossRef]
${ }^{17}$ Liaw, C. C.; Chang, F. R.; Chen, Y. Y.; Chiu, F. F.; Wu, M. J.; Wu, Y. C. J. Nat. Prod. 1999, 62, 1613. [CrossRef] [PubMed]

${ }^{18}$ Alali, F. Q.; Liu, X. -X.; McLaughlin, J. L. J. Nat. Prod. 1999, 62, $504 . \quad$ [CrossRef] [PubMed]

${ }^{19}$ Costa, E. V.; Pinheiro, M. L. B.; Souza, A. D. L.; Barison, A.; Campos, F. R.; Valdez, R. H.; Ueda-Nakamura, T.; Dias Filho, B. P.; Nakamura, C. V. Molecules 2011, 16, 9714. [CrossRef] [PubMed]

${ }^{20}$ Camacho, M. D. R.; Phillipson, J. D.; Croft, S. L.; Solis, P. N.; Marshall, S. J.; Ghazanfar, S. A. J. Ethnopharmacol. 2003, 89, 185. [CrossRef] [PubMed]

${ }^{21}$ Fumarola, L.; Spinelli, R.; Brandonisio, O. Res. Microbiol. 2004, 155, 244. [CrossRef] [PubMed]

${ }^{22}$ Torres-Santos, E. C.; Moreira, D. L.; Kaplan, M. A. C.; Meirelles, M. N.; Rossi-Bergmann, B. Antimicrob. Agents Chemother. 1999, 43, 1234. [PubMed] [Link]

${ }^{23}$ Pinheiro, M. L. B.; Xavier, C. M.; de Souza, A. D. L.; Rabelo, D. M.; Batista, C. L.; Batista, R. L.; Costa, E. V.; Campos, F. R.; Barison, A.; Valdez, R. H.; Ueda-Nakamura, T.; Nakamura, C. V. J. Braz. Chem. Soc. 2009, 20, 1095. [CrossRef]

${ }^{24}$ Février, A.; Ferreira, M.E.; Fournet, A.; Yaluff, G.; Inchausti, A.; Arias, A. R.; Hocquemiller, R.; Waechter, A. S. Planta Med. 1999, 65, 47. [CrossRef] [PubMed]

${ }^{25}$ Osorio, E.; Arango, G. J. A.; Jimenez, N.; Alzate, F.; Ruiz, G.; Gutierrez, D.; Paco, M. A.; Gimenez, A.; Robledo, S. J. Ethnopharmacol. 2007, 111, 630. [CrossRef] [PubMed]

${ }^{26}$ Queiroz, E. F.; Roblot, F.; Cavé, A. J. Nat. Prod. 1996, 59, 438. [CrossRef] [PubMed]

${ }^{27}$ Waechter, A. I.; Cavé, A.; Hocquemiller, R.; Bories, C.; Muñoz, V.; Fournet, A. Phytother. Res. 1999, 13, 175. [CrossRef] [PubMed]

Croft, S. L.; Coombs, G. H. Trends Parasitol. 2003, 19, 502. [CrossRef] [PubMed] 